DOI: $\underline{\text { https://doi.org/10.24867/07DS13Kresojevic }}$

\title{
СТАВОВИ И ПОНАШАҢА ВОЗАЧА НА ДВОТРАЧНИМ КРУЖНИМ РАСКРСНИЦАМА У РЕПУБЛИЦИ СРПСКОЈ
}

\section{ATTITUDES AND BEHAVIOR OF DRIVERS AT TWO-LANE ROUNDABOUTS IN REPUBLIC OF SRPSKA}

\author{
Саша Кресојевић, Вук Богдановић, Факултет техничких наука, Нови Сад
}

\section{Област-САОБРАһАJ}

Кратак садршај - У оквиру рада се врии прорачун капацитета раскрснице по НСМ 2016 приручнику, испитивање ставова возача о овим раскрсницама, упоређивање понашања у реалном саобраћајном току са ставовима и законском регулативом.

Кључне ријечи: Двотрачне кружне раскрснице, капацитет, протурјечности у закону

Abstract - In this paper calculation of capacity in twolane roundabout by HCM 2016 and examination of driver's attitudes is given. In addition, driver's behavior in the real traffic flow with driver's attitudes and legislation is compared.

Keywords: Two-lane roundabout, capacity, law contradiction.

\section{1 УВОД}

Раскрсница је површина на којој се укрштају или спајају два пута или више путева, као и шира саобраћајна површина која настаје укрштањем, односно спајањем путева [1]. С обзиром да возила користе исту површину којом се крећу у различитом времену, раскрсница представља изазов како у погледу безбиједности, тако и у погледу капацитета. Кретање саобраћајних токова у раскрсници се мора прецизно регулисати како се не би дешавали застоји и конфликтне ситуације. Приоритет саобраћајних токова на раскрсницама се регулише на сљедеће начине:

- Општим правилима саобраћаја,

- Саобраћајним знацима приоритета,

- Свјетлосном сигнализацијом.

Раскрснице се према директности дијеле на (ауторова подјела):

- Раскрснице са директним укрштањем саобраћајних токова,

- Кружне раскрснице и петље гдје се токови индиректно укрштају.

\section{2 СТАНДАРДНЕ КРУЖНЕ РАСКРСНИЦЕ}

Елементи стандардне кружне раскрснице су [1]:

- Кружни коловоз који представља површину којом се возила крећу око централног острва у смијеру супротном од смијера кретања казаљке на сату;

\section{NAPOMENA:}

Овај рад проистекао је из мастер рада чији ментор је био др Вук Богдановић.
- Централно острво које је денивелисана физичка препрека кружног или овалног облика, постављена у центру кружне раскрснице, која спријечава праволинијско кретање у раскрсници и омеђава кружну раскрсницу са унутрашње стране;

- Прегазни дио централног острва је онај дио централног острва који заједно са кружним коловозом омогућава кретање дугих возила кроз раскрсницу;

- Спољњи пречник кружне раскрснице је пречник спољне ивице кружног коловоза.

- Унутрашњи пречник је пречник централног острва.

- Краци кружне раскрснице су саобраћајнице из којих се возила улијевају и излијевају из кружне раскрснице;

- Улазни радијус је радијус десне ивице коловоза на улазу у кружну раскрсницу;

- Излазни радијус је радијус десне ивице коловоза на излазу из кружне раскрснице;

- Раздјелно острво је денивелисани елемент кружне раскрснице који раздваја улив и излив из кружне раскрснице, обезбјеђује простор за краткотрајно задржавање пјешака при преласку крака кружне раскрснице и позиционира возила за правилно улажење у кружну раскрсницу;

- Унутрашња саобраћајна трака је она која се налази уз лијеву ивицу коловозне траке гледајући у дозвољеном смијеру кретања;

- Спољња саобраћајна трака се налази уз десну ивицу коловозне траке гледајући у дозвољеном смијеру кретања.

Карактеристике стандардних кружних раскрсница су следеће [2, p. 102]:

- Возила у кржној раскрсници имају право првенства у односу на возила која улазе у кружну раскрсницу;

- Возила која улазе у кружну раскрсницу не заустављају се ако имају слободан улаз, већ улазе у кружну раскрсницу са смањеном брзином;

- Пјешаци и бициклисти у кружним раскрсницама поштују иста правила као и у класичним раскрсницама;

- Дуга возила смију да користе калдрмисани или издигнути дио око кружног острва.

Основна предност стандардних кружних раскрсница у односу на друге облике укрштања се огледа у следећем: 
- Брзина одвијања саобраћаја је релативно мала, па су посљедице саобраћајних незгода релативно мале;

• Визуелно су најприхватљивије.

Основни недостаци кружних раскрсница су:

- Потребна већа површина за изградњу,

- Повећање дужине пјешачких путања.

Према броју саобраћајних трака у самој раскрсници, кружне раскрснице се дијеле на:

- Једнотрачне и

- Вишетрачне.

Алтернативне кружне раскрснице су се јавиле након стандарних, а са циљем да се кружне раскрснице унаприједе и прилагоде новим захтјевима.

Неке од варијанти оваквих раскрсница су:

- Турбо кружне раскрснице,

- Семафорисане кружне раскрснице и

- Денивелисане кружне раскрснице.

\section{3 ЗАКОНСКА РЕГУЛАТИВА}

На нивоу Босне и Херцеговине и Републике Српске област саобраћаја се уређујуе:

1. Закон о основама безбједности саобраћаја на путевима Босне $и$ Херцеговине, а који област интересовања посебно дотиче у сљедећим члановима (скраћено ЗОБС БиХ) [1].

- Члан 48.

(1) Возач возила које скреће удесно дужан је обавити скретање крећући се крајњом саобраћајном траком која се протеже уз десну ивицу коловоза, осим ако саобраћајним знаком или ознаком на коловозу није другачије одређено.

(2) Возач возила које скреће улијево дужан је обавити скретање крећући се крајњом лијевом саобраћајном траком која се протеже уз средишњу линију и уз замишљени или обиљежени лук који спаја двије средишње линије бочних коловоза, односно саобраћајном траком која се протеже уз лијеву ивицу пута с једносмјерним саобраћајем, осим ако саобраћајним знаком на путу није другачије одређено.

- Члан 50.

(3) Возач је дужан, пред раскрсницом, возилом заузети положај на довољној удаљености на оној саобраћајној траци којом мора проћи кроз раскрсницу.

2. Правилник о саобраћајним знаковима и сигнализацији на путевима, начину обиљежсвања радова и препрека на путу и знаковима које учесницима у саобраћају даје овлаштено лице (скраћено - правилник) [3], а који ову област посебно дотиче у сљедећим члановима:

- Члан 29.

(1) знак »наилазак на пут са првенством пролаза« (II-1) обиљежава близину укрштања, односно спајања на ком возач мора дати предност свим возилима која се крећу путем на који он наилази.

\section{3. Законом о безбједности саобраћаја на путевима} Републике Српске [4]

\section{4 БЕЗБЈЕДОНОСНИ АСПЕКТ}

Параметар на основу кога се може сагледати ниво безбиједности раскрснице јесте број конфликтних тачака. Конфликтне тачке представљају мјеста на којима се саобраћајни токови:

- укрштају

- преплићу

- спајају

- раздвајају.

Конфликтне тачке укрштања су најзахтјевније са становишта процјењивања саобраћајне ситуације и групишу се у конфликтне тачке првог ранга, након тога преплитање спада у други ранг, док конфликтне тачке спајања и раздвајања представљају најмању опасност у саобраћају, те се сврставају у трећу групу [5, p. 28]

У поређењу са стандардним четверококраким раскрсницама (које имају тридесет двије), једнотрачне кружне раскрснице имају мањи број (осам) конфликтних тачака. Ове раскрснице такође немају конфликтне тачке укрштања. Након једнотрачних кружних раскрсница, а у настојању да се повећа капацитет ових раскрсница, конструисане су кружне раскрснице које имају двије саобраћајне траке на кружном коловозу и двије траке на улазним и излазним крацима. У литератури се сматра да стандардне двотрачне кружне раскрсница имају максимално 32 конфликтне тачке [6, р. 138], међутим због специфичности у правној регулативи Босне и Херцеговине, односно Републике Српске, могу се пронаћи још неке конфликтне ситуације, те тако укупан број конфликтних тачака износи 40 (Слика 1).

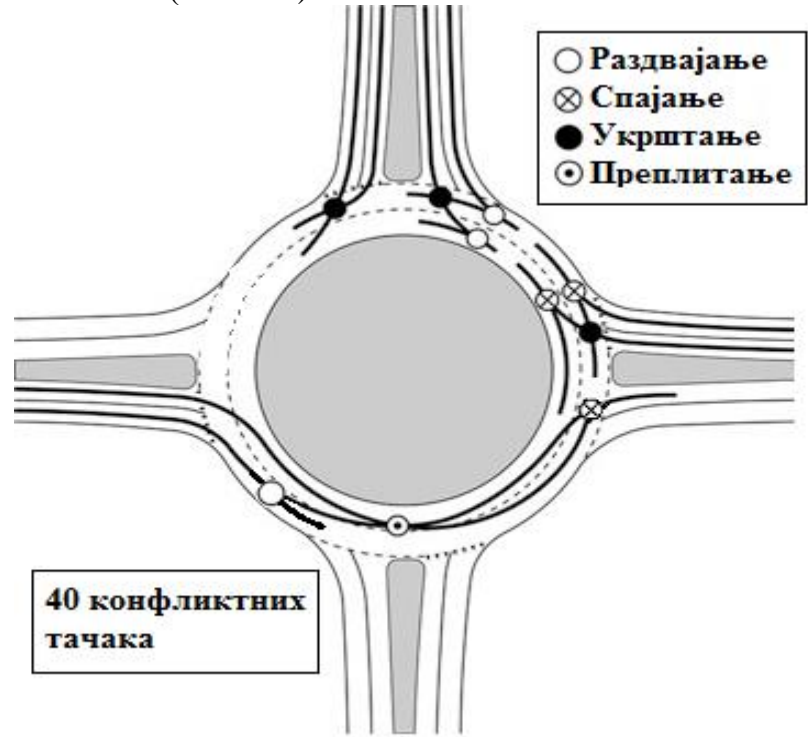

Слика 1. Конфликтне тачке на двотрачним кружним раскрсницама у Републици Српској (дорађено [5])

Турбо кружне раскрснице су варијанта кружних раскрсница која омогућава повећање капацитета, а са друге стране број конфликтних тачака се не повећава као код стандардних двотрачних кружних раскрсница, те су са становишта безбједности прихватљивије.

\section{5 ИСТРАЖИВАњЕ}

За потребе овог рада подаци су прикупљани помоћу:

1. Снимања саобраћаја на раскрсници из ваздуха (метод посматрања и бројања) и 
2. Испитивања ставова возача (метод тзв. ,google forms“ анкете).

\section{1 Снимање саобраћаја}

За потребе овг рада саобраћај је сниман камером из ваздуха, а касније је снимак репродукован и информације уписане у "MS Excel" табелу.

Снимање саобраћаја је вршено на западном транзиту у граду Бањој Луци, односно на мјесту укрштању улице Ивана Горана Ковачића и улице Марије Димић, те пута Е-661 (М-16). Раскрсница је снимљена у петак 17. маја 2019. године у периоду од $15: 45$ до $16: 45$, а детаљно је анализиран период од 16:00 до 16:15.

За поменутих 15 минута кроз кружну раскрсницу је прошло 1249 возила (табела 1).

Табела 1. Проток возила (од 16 до 16:15)

\begin{tabular}{|c|c|c|}
\hline $\begin{array}{l}\text { Бр. возила } \\
\text { Улаз }\end{array}$ & Сао. трака & Укупно \\
\hline \multirow{2}{*}{ Бања Лука } & 1 & 233 \\
\hline & 2 & 203 \\
\hline Бања Лука бајпас & 1 & 46 \\
\hline \multirow{2}{*}{ Лакташи } & 1 & 221 \\
\hline & 2 & 213 \\
\hline \multirow{2}{*}{ Лазарево } & 1 & 74 \\
\hline & 2 & 47 \\
\hline Лазарево бајпас & 1 & 108 \\
\hline \multirow{2}{*}{ Петрићевац } & 1 & 69 \\
\hline & 2 & 35 \\
\hline Укупно & & 1249 \\
\hline
\end{tabular}

Прегледавањем снимка је такође уочено да се 9\% возача престроји при изласку из кружне раскрснице из унутрашње траке, а да 16\% оних који се крећу ка трећем излазу користе спољњу траку.

\subsection{1 Капацитет кружних раскрсница}

У теорији саобраћајног тока, капацитет представља максималан проток, односно максималан број возила која у јединици времена могу проћи преко дефинисаног пресјека пута. Максималан проток, односно капацитет сваког путног објекта, остварује се у режиму засићеног тока.

Метод за прорачун капацитета који је коришћен у овом поглављу дефинисан је у приручнику НСМ 2016 [7]. Вриједности добијене за капацитет су преко коефицијента засићености упоређене са захтјевом за протоком добијеним бројањем.

Коефицијент засићености представља однос захтјева за протоком и капацитета

$$
x_{i}=\frac{v_{i}}{c_{i}}
$$

Гдје је:

$$
\begin{array}{ll}
x_{i} & \text { - коефицијент засићености } \\
v_{i} & \text { - захтјев за протоком (возила/час) } \\
c_{i} & \text { - капацитет (возила на час) }
\end{array}
$$

Коефицијент засићености по саобраћајним тракама на основу једначине 1 дат је у табели 2.
Табела 2. Засићеност саобраћајног тока

\begin{tabular}{|l|r|r|} 
Улаз & \multicolumn{1}{c}{ Сао. трака } & \multicolumn{1}{c|}{ Засићеност } \\
\hline \multirow{2}{*}{ Бања Лука } & 1 & 1,3 \\
\cline { 2 - 3 } & 2 & 1,3 \\
\hline \multirow{2}{*}{ Бања Лука бајпас } & 1 & 0,3 \\
\hline \multirow{2}{*}{ Лакташи } & 1 & 1,3 \\
\hline \multirow{2}{*}{ Лазарево } & 2 & 1,3 \\
\hline Лазарево бајпас & 1 & 1,0 \\
\hline \multirow{2}{*}{ Петрићевац } & 2 & 1,1 \\
\cline { 2 - 3 } & 1 & 1,5 \\
\hline
\end{tabular}

\section{2 Испитивање ставова возача преко, google} forms"-a

Испитивање ставова возача је вршено преко тзв. гугл анкете. Анкета је израђена и постављена на гугл налог, а након тога је посредством друштвених мрежа, слањем групних мејлова и вибер порука дошла до испитаника. Линк на који је постављена анкета је: https://forms.gle/YQ7XExFypi6iTsDN8

Путем анкете су испитивани ставови возача у Републици Српској, а нагласак је био на перцепцији, познавању прописа и понашању возача у двотрачним кружним раскрсницама. Анкета је спровођена у периоду од 4.8.2019 до 4.9.2019. године, сачињена је од 12 питања, а урађена је на узорку од 329 испитаника. На основу Хедонове матрице на услове одвијања саобраћаја и ризик настанка саобраћајне незгоде утичу: човјек, возило, пут [8, p. 104]. У оквиру рада је анализиран човјеков утицај. У склопу спроведене анкете су испитиване различите предиспозиције које могу предодредити возачево понашање у кружној раскрсници. Питање које се посеобно издваја је оно о познавању саобраћајних прописа гдје су анкетирани рекли да њих 50\% одлично, а 40\% врло добро познају прописе који се тичу саобраћаја.

Након испитивања предиспозиција, испитаницима су предочене конкретне ситуације у двотрачним кружним раскрсницама, а на којима се види несигурност испитаника (питања од 10. до 12.).

У 10. питању је тражено мишљење о томе да ли возило које чека да се укључи у кружну раскрсницу из спољње траке на прилазу треба да пропусти возила која се крећу унутрашњом траком кружне раскрснице или може да уће спољњом саобраћајном траком у раскрсницу (ако нема возила у спољњој траци), гдје је $58 \%$ испитаника рекло да се возило може укључити у спољьу траку. Једанаесто питање је везано за мишљење о начину напуштања кружне раскрснице из унутрашње саобраћајне траке, а гдје је 27\% испитаника рекло да се возило мора престројити у спољњу саобраћајну траку а тек након тога напустити раскрсницу. У посљедњем питању је тражено мишљење о томе да ли возач који се креће спољњом саобраћајном траком у двотрачној кружној раскрсници и жели исту да напусти на трећем излазу поступа исправно. Одговори на ово питање су такви да је 23\% испитаника ово понашање оцијенило као исправно. 


\section{6 ПОРЕЪЕЊЕ РЕЗУЛТАТА И ДИСКУСИЈА}

Приликом упоређивања резултата бројања и резултата анкете види се да је већи број оних који сматрају да је кретање возилом ка трећем излазу спољњом траком исправно (23\%) у односу на оне који се тако понашају $(16 \%)$. Уколико се излазак из четворокраке кружне раскрснице на трећи излаз сматра радњом скретања возила у лијеву страну, онда важи члан 48, став 2, ЗОБС-а БиХ. У том случају би возач за излазак из четворокраке раскрснице на трећем излазу био у обавезан користити унутрашњу саобраћајну траку.

Правилник знаком II-1 је јасно дефинисано да возило које улази у кружну раскрсницу мора да пропусти сва возила која се налазе у раскрсници, а из претходног поглавља видимо да $58 \%$ не би поступило на овакав начин у конкретној ситуацији. Двадесет седам процената испитаника сматра да се возило мора престројити у крајњу десну траку приликом искључења из кружне раскрснице, а из резултата бројања увиђамо да се само 9\% возача понашало на такав начин. Упориште за такво понашање се може пронаћи у $3 О Б С-y$ Би X, члан 50, став 3 , гдје се каже да је возач дужан, прије раскрснице, да возилом заузме положај у оној саобраћајној траци којом ће напустити раскрсницу. Ако се овој ситуацији дода члан 48, став 2 истог закона, закључује се да возило које је ушло из унутрашње траке на прилазу, не може искључити крајњом десном траком и наставити кретање истом траком, гдје се увиђа протурјечност.

\section{7 ЗАКЉУЧАК И ПРИЈЕДЛОГ МИЈЕРА}

Кружне раскрснице представљају креативно рјешење помоћу кога се рјешава проблем директног укрштања путева. Овај тип раскрсница је у задњих двадесетак година изузетно популаран на простору Босне и Херцеговине. Имајући у виду мањи број конфликтних тачака и низ других предности, једнотрачне кружне раскрснице имају позитине критике, како од стране стручне јавности, тако и од самих корисника.

Одређене нејасноће се јављају на двотрачним кружним раскрсницама, те су оне предмет интересовања у овом раду. У оквиру рада је вршено истраживање које је за циљ имало прикупљање података о ставовима и понашању возача на двотрачним кружним раскрсницама у Републици Српској. Ставови су испитивани путем ,google“ анкете, док је понашање испитивано снимањем саобраћаја на раскрсници пута Е-661 и улица Ивана Горана Ковачића и Марије Димић. На основу понашања возача и укупне законске регулативе закључено је да на двотрачним кружним раскрсницама постоје додатне конфликтне тачке, односно њих 40. Стварни капацитет добијен бројањем одступа (већи је) од прорачуна по НСМ-u 2016 и то у појединим случајевима и до $35 \%$ (табела 2). Разлог оваквог одступања може бити спремност возача да се укључе у раскрсницу при мањем временском и просторном јазу. Закон који уређује ову област је протурјечан, а што се најјасније може закључити из чланова 48 и 50 ЗОБС-а БиХ. Посљедица ове протурјечности јесте немогућност поступања у складу са законом, ако желимо да се возилом искључимо на трећем излазу. Индикатор који је везана за ову протурјечност је то да возачи, њих 84\% користи унутрашњу саобраћајну траку за кретање ка трећем излазу у односу на 77\% који сматрају да је то исправно.

Приједлог рјешења:

I. Измијенити и ускладити законе како чланови закона не би били протурјечни и како би на најбољи могући начин били подршка унапријеђењу и модернизациј процеса одвијања саобраћаја.

II. Допунити правилник хоризонталном и вертикалном сигнализацијом како би се прецизно одредило која улазна саобраћајна трака се може користити, зависно од излаза на коме ће возач напустити раскрсницу.

III. Допунити постојеће смјернице за планирање, пројектовање, грађење и одржавање путева у БиХ на начин да се:

- умјесто двотрачних кружних раскрсница, гдје год је то могуће, пројектују и граде турбо кружне раскрснице

- обиљеже раскрснице тако да возило буде вођено кроз раскрсницу

IV. Периодичним, обавезним часовима, едуковати возаче о новитетима у процесу одвијања саобpaћaja.

\section{8 ЛИТЕРАТУРА}

[1] ЗОБС, Закон о основама безбједности саобраћаја на путевима у Босни и Херцеговини, Сарајево: Службени гласник Босне и Херцеговине, 06/06, 75/06, 44/07, 84/09, $48 / 10,18 / 13,8 / 17,89 / 17$ и $9 / 18$

[2] “Смјернице за пројектовање, грађење, одржавање и надзор на путевима,” Сарајево/Бања Лука, 2005.

[3] Правилник о саобраћајним знаковима и сигнализацији на путевима, начину обиљежавања радова и препрека на путу и знаковима које учесницима у саобраћају даје овлаштено лице, Службени гласник Босне и Херцеговине, 16/07, 61/07.

[4] ЗБС РС, Закон о безбједности саобраћаја на путевима ?епублике Српске, Бања Лука: Службени гласник ?епублике Српске, 63/11.

[5] T. Tollazzi, Alternative Types of roundabout: An Informational Guide, New York: Springer, 2014.

[6] L. V. S. S. Ana Bastos Silva, "Moving from Conventional Roundabouts to Turbo-Roundabout," in Euro Working Group on Transportation, 2013.

[7] HCM, Highway capacity manual, Washingnton, DC: Transportation research board of the national academies, 2016.

[8] К. Липвац, Безбједност саобраћаја, Београд: Јавно предузеће Службени лист СРЈ, 2008.

\section{Кратка биографија:}

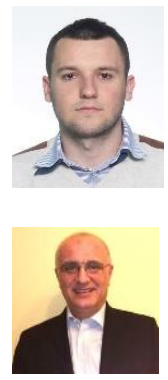

Саша Кресојевић рођен у Градишци 1993. год. Мастер рад на Факултету техничких наука из области саобраћаја одбранио 2019. год.

Вук Богдановић рођен у Сремској Митровици 1966. год. Од 1993 год ради на Факултету техничх наука Универзитета у Новом Саду 